\title{
Labour
}

Journal of Canadian Labour Studies

Le Travail

Revue d'Études Ouvrières Canadiennes

\section{Regulating Employment Precarity in Ontario Home Care}

\section{Timothy J. Bartkiw}

Volume 86, automne 2020

URI : https://id.erudit.org/iderudit/1074472ar

DOI : https://doi.org/10.1353/1lt.2020.0036

Aller au sommaire du numéro

\section{Éditeur(s)}

Canadian Committee on Labour History

\section{ISSN}

0700-3862 (imprimé)

1911-4842 (numérique)

Découvrir la revue

\section{Citer cet article}

Bartkiw, T. (2020). Regulating Employment Precarity in Ontario Home Care. Labour / Le Travail, 86, 45-69. https://doi.org/10.1353/llt.2020.0036

\section{Résumé de l'article}

Au milieu des années 1990, la province de l'Ontario a instauré un nouveau modèle de «concurrence gérée» pour régir une part importante de la prestation des services de soins à domicile. Le nouveau modèle, fondé sur un appel d'offres pour la prestation de services de soins à domicile, a renforcé le recours à des "organisations de prestataires de services" privées et de plus en plus à but lucratif. Avec le temps, les résultats de la transition vers une concurrence gérée - en particulier l'augmentation de la précarité de l'emploi et le roulement du personnel - sont devenus de plus en plus marquants et ont été pris en compte dans la documentation antérieure. Cependant, une série de réponses ultérieures à ces résultats ont également commencé à émerger, visant ostensiblement à améliorer les conditions de travail et d'emploi dans ce secteur. Cet article présente une analyse historique des diverses réponses à la précarité accrue de l'emploi provoquée par le régime de concurrence gérée dans les soins à domicile de l'Ontario, en mettant l'accent sur les préposés au soutien à la personne dans la mesure où ils ont toujours eu tendance à vivre les conditions les plus précaires parmi les professions de soins à domicile. L'analyse suggère que l'arrangement institutionnel de base du travail fissuré et des relations organisationnelles, associé à une structure de négociation hyper décentralisée, était une contrainte et un facteur de médiation clés. La mesure politique la plus dramatique visant la précarité de l'emploi, l'initiative d'amélioration des salaires des préposés au soutien à la personne de 2014, a constitué une dérogation majeure et ad hoc de cette structure qui avait jusque-là mis en place une modération salariale avec tant de succès qu'elle a remis en question les objectifs du gouvernement en matière de ressources humaines en santé. Ce recours à un instrument ad hoc aussi extraordinaire, sans aborder la structure institutionnelle de base, restreint considérablement le degré d'amélioration des résultats d'emploi des préposés au soutien à la personne susceptibles d'être produits par la négociation collective dans les soins à domicile en Ontario.
Ce document est protégé par la loi sur le droit d'auteur. L’utilisation des services d’Érudit (y compris la reproduction) est assujettie à sa politique d'utilisation que vous pouvez consulter en ligne.

https://apropos.erudit.org/fr/usagers/politique-dutilisation/ 


\title{
Regulating Employment Precarity in Ontario Home Care
}

\author{
Timothy J. Bartkiw, Ryerson University
}

THE CHANGING NATURE OF WORK and employment conditions in paid care work has been an important social phenomenon and area of scholarship in recent decades. ${ }^{1}$ In the context of neoliberal austerity, care work has been increasingly commodified and subjected to new public management practices such as contracting out and privatization of provision. ${ }^{2}$ In Canada and elsewhere, these home care reforms were part of a larger project of healthcare-sector restructuring in recent decades. The essence of this restructuring moved home care toward a cost-effective instrument within the broader field of health care. This shift, already underway in the early 2000s, was sanctioned in the influential 2002 "Romanow Report," which called for increased reliance on home care services in Canada and has been interpreted by many as providing a normative green light for outsourcing and privatization in this subsector. ${ }^{3}$

1. Sara Charlesworth, "Decent Working Conditions for Care Workers? The Intersections of Employment Regulation, the Funding Market and Gender Norms," Australian Journal of Labour Law 25, 2 (January 2012): 107-129.

2. Paul Leduc Browne, The Commodity of Care: Home Care Reform in Ontario (Ottawa: Canadian Centre for Policy Alternatives, 2003); Donna Baines \& Ian Cunningham, "Care Work in the Context of Austerity," Competition and Change 19, 3 (April 2015): 183-193.

3. Canada, Commission on the Future of Health Care in Canada, Building on Values: Commission on the Future of Health Care in Canada - Final Report (Ottawa 2002).

Historically, home care has not been treated as a core, insured health service but rather is recognized under the Canada Health Act as a kind of "extended health service," enabling significant differences in its regulation compared to core health services. See Pat Armstrong, Madeline Boscoe, Barbara Clow, Karen Grant, Ann Pederson, Kay Willson, Olena Hankivsky, Beth Jackson \& Marina Morrow, Reading Romanow: The Implications of the Final Report of 
In the mid-1990s, the province of Ontario instituted a new model for a significant portion of home care services delivery - referred to as "managed competition" - which involved a sharp turn toward a competitive model of contracting out home care services. The new contracting model deepened reliance upon private and increasingly for-profit service provider organizations (SPOs) in home care service provision. This new model is based on a competitive bidding process, increasing labour-cost-based competition among sPos. ${ }^{4}$ As Cynthia Cranford, Angela Hick, and Louise B. Bauer note, the new model forged "fragmented employment relations between the state funder, employing organizations, clients, and workers - who are primarily immigrant women of colour" and these employment relations shape a "complex labour process where relations between workers and clients in the home-workplaces can be both consensual and tense." 5 This increasingly fragmented, or fissured, organizational structure enables government to extract the benefits of de facto monopolistic employer power vis-à-vis workers ostensibly employed by subordinate, subcontracting organizations, which is an increasingly common pattern in the delivery of community and related services. ${ }^{6}$

Prior research and analysis show that within a few years of the shift to the new managed competition model in Ontario, employment precarity for home care workers grew significantly. Researchers found that precarity was multifaceted, measured in terms of wages, employment security, and working-hours stability, particularly for personal support workers (PSWs). ${ }^{7}$ PSWs in the sector are predominantly female and deliver the largest category of services. ${ }^{8}$ In addition, non-profit and community-based organizations that previously delivered

the Commission on the Future of Health Care in Canada for Women, revised and updated ed. (Toronto: National Coordinating Group on Health Care Reform and Women, 2003).

4. These Spos, which hire workers to provide care to third-party clients and home care patients, are sometimes referred to as "agencies," especially by critics of the managed competition structure. While I do use "SPO" and/or "service provider" (the terms preferred by these organizations), this is not intended to signal any particular degree of normative support for current organizational arrangements in the home care system.

5. Cynthia Cranford, Angela Hick \& Louise B. Bauer, "Lived Experiences of Social Unionism: Toronto Homecare Workers in the Late 2000s," Labor Studies Journal 43, 1 (March 2018): 74-96.

6. David Weil, The Fissured Workplace: Why Work Became So Bad for So Many and What Can Be Done to Improve It (Cambridge, MA: Harvard University Press, 2014); Charlesworth, "Decent Working Conditions."

7. Dara Zarnett, Peter C. Coyte, Eric Nauenberg, Diane Doran \& Audrey Laporte, "The Effects of Competition on Community-Based Nursing Wages," Healthcare Policy 4, 3 (February 2009): 129-144; Jane Aronson, Margaret Denton \& Isik Zeytinoglu, "Market-Modelled Home Care in Ontario: Deteriorating Working Conditions and Dwindling Community Capacity," Canadian Public Policy 30, 1 (March 2004): 111-125.

8. Accenture Inc., Fee-for-Service Market Assessment: Recommendations for a Pricing Model for Home Care Services in Ontario (Toronto, October 2013), 26. 
publicly funded home care services were destabilized as their relationship to the sector was undermined. ${ }^{9}$ SPOS themselves also experienced increased challenges in terms of employee retention, with high rates of employee exit. This high turnover raises concerns about service quality and organizational sustainability across the sector. ${ }^{10}$ In time, the outcomes of the transition to managed competition grew increasingly salient. However, a series of policy responses to these outcomes also began to emerge, aimed at improving work and employment conditions in the sector.

This project involved a historical analysis of various significant responses to the heightened employment precarity wrought by the managed competition regime in Ontario home care. The project focused on PSws insofar as they have historically tended to experience the most precarious conditions among the primary home care occupations. ${ }^{11}$ The goal was to document and assess the various responses for the purpose of increasing our understanding of the role of policy in constructing and remedying employment precarity in this large and salient case of care work outsourcing in Ontario. The project involved a review and analysis of various archival documents; organizational documents, reports, and publications; policy documents; legislation; regulations; and decisions of the Ontario Labour Relations Board (OLRB). Internal Ontario government documentation pertaining to home care employment conditions that was produced in response to a freedom of information request filed with the Ministry of Health and Long-Term Care (монцтC) was also reviewed and analyzed. Further, in order to assess responses emerging from the realm of collective bargaining, a database of collective agreements pertaining to PSW bargaining units within the managed competition subsector was constructed and analyzed. ${ }^{12}$ Finally, the project also involved reviewing

9. Zarnett et al., "Effects of Competition"; Aronson et al., "Market-Modelled Home Care." See also Catherine-Rose Stocks-Rankin, "Who Cares about Ownership? A Policy Report on For-Profit, Not-for-Profit and Public Ownership in Ontario Long-Term Care," master's thesis, Centre for International Public Health Policy, Edinburgh University, 2008.

10. Zarnett et al., "Effects of Competition"; Aronson et al., "Market-Modelled Home Care."

11. Accenture, Fee-for-Service, 26.

12. What may generally be called the "home care" sector includes various work activities beyond those that are the focus of this study. This article focuses primarily on Psw home care work governed by the managed competition regime. Thus, the database does not include any collective agreements that relate only to work outside of the managed competition regime. Also, the database was not complete, since many collective agreements were never registered with the ministry. The sample of collective agreements was based on what was available from the government, and the Ministry of Labour (MOL) unfortunately did not have a clear subcategory for this subsector. In order to focus on contracts under the managed competition regime, the MOL conducted an over-inclusive search request based on relevant NAICS codes, which contained many contracts pertaining to types of work and services that were similar but outside of the CCAC subsector. Then, we cross-referenced this large list of contracts on file with annual lists of the names of sPOs contracted by each CCAC, available in CCAC annual reports, in order to identify contracts pertaining to the CCAC subregime. By inspection, we further 
all submissions filed by all relevant home care sector organizations with the Ontario Changing Workplaces Review (CWR), a provincial labour and employment law reform process held from 2015 to $2017 .^{13}$ These submissions contained further particulars of the conditions of home care employment and positions taken by key organizations concerning potential labour/employment law reform, both in general and with respect to this sector. ${ }^{14}$

\section{Historical Context: Ontario Home Care and Healthcare Restructuring}

Although home Care Services of various sorts have existed in Canada in charitable form since the Victorian Order of Nurses (vON) began providing them in the late 19th century, the emergence of Canadian state-supported home care services can largely be traced to the 1950s. Early home care initiatives in Ontario emerged alongside a growth in private nursing homes and homes for the aged, in a context of increasing life expectancy and a decline in the postwar family capacity to provide necessary care for the elderly and infirm. Crucial to its emergence from this early stage onwards was the view that hospitals were being overwhelmed by a bottleneck in chronic care (particularly for the aged). This led hospital administrators to initiate pilot home care programs, particularly in urban areas, to ease the burden on hospital beds and resources. A key experimental project in Toronto from 1958 to 1964 involving the Toronto Welfare Council, the city's Department of Health, the von, and the Toronto General Hospital provided various categories of home care services resembling those still in place today, including nursing, social, homemaker,

narrowed the sample to those pertaining to bargaining units of PSW workers. This produced a sample of 81 contracts during the years from 2000 to 2015.

13. The CWR process involved two separate stages of public consultation and submissions. The database constructed included all submissions filed by home care organizations in both stages. All of the CWR's official reports, academic reports commissioned by the CW $\mathrm{R}$, and stakeholder submissions filed with the $\mathrm{CWR}$ are available online as of the date of publication: "Ontario Changing Workplaces Review," Industrial Relations and Human Resources Library Digital Collections, Centre for Industrial Relations and Human Resources, University of Toronto, https:/cirhr.library.utoronto.ca/digital-collections/ontario-changing-workplaces-review.

14. To obtain further insights and clarity, we conducted twenty interviews with key informants from multiple relevant organizations in the sector. Interviews were typically one to two hours in length, conducted in person and/or by telephone, and subsequently transcribed and coded using NVivo software. Key informants were selected from various relevant organizations, including two labour union organizations representing the vast majority of unionized PSW employees, a PSW professional association, home care SPOS, two separate home care provider industry associations, the Ontario Association of Community Care Access Corporations (OACCAC), the umbrella body representing the various Community Care Access Corporations (CCACs) charged with implementing and administering managed competition, and a lobby group called the Ontario Health Coalition. The sample of key informants was a purposive one. Informants were selected from within relevant organizations based on their ability to speak to the core research objective. 
physical rehabilitation, and ancillary services. The program included all voluntarily willing patients discharged from participating hospitals, with costs to patients covered by basic hospital insurance, reducing its stigma as relief for the poor. Although evidence of the program's success remained somewhat contested, it helped generate support for home care expansion. ${ }^{15}$

Throughout subsequent decades, home care services in Ontario expanded gradually, although this was constrained by various factors. Importantly, there remained a lack of sufficient consensus on its policy rationale. On one hand was the notion that home care was a necessary and improved form of care embedded in the community that ought to be broadly available, built upon existing non-profit homemaking services, and available without means testing, so as to protect its broad appeal. On the other hand lay the notion that home care had primarily a fiscal purpose, in relation to the high cost of hospitals and institutionalization. Under the latter logic, home care service expansion not only depended upon utilization of low cost, predominantly female-provided care work but also, in the eyes of various policymakers, was understood as bearing the contradictory potential to undermine the provision of unpaid care by family members, primarily women. ${ }^{16}$

By the late 1980s and early 1990s, the cost-savings policy rationale for home care services gained prominence in the context of significant fiscal deficits at both federal and provincial levels. The federal government's corresponding reduction in transfers to the provinces for healthcare expenditures further placed downward pressures on the sector. The exclusion of home care from the Canada Health Act's five conditions pertaining to "mainstream" health care effectively incentivized provincial governments to expand home care, with increasing reliance on privatization - an expansion that increasingly facilitated the possibility of cuts elsewhere in health care. ${ }^{17}$ As a result, the government made significant cuts in the number of hospitals and hospital beds throughout the 1990s..$^{18}$

In the early 1990s, a somewhat fragmented structure in home care delivery and administration existed in Ontario. Services were administered by two separate government ministries: the Ministry of Health and the Ministry of Community and Social Services. However, service delivery was dominated by external non-profit organizations such as the Red Cross, the von, and the March of Dimes. These organizations employed home care workers and delivered services under long-term relationships with government. In response

15. James Struthers, "No Place like Home': Gender, Family, and the Politics of Home Care in Post-World War II Ontario," Canadian Bulletin of Medical History 20, 2 (Fall 2003): 391-397.

16. Struthers, "No Place like Home," 403.

17. Patricia M. Baranek, Raisa B. Deber \& A. Paul Williams, Almost Home: Reforming Home and Community Care in Ontario (Toronto: University of Toronto Press, 2004); Armstrong et al., Reading Romanow.

18. Browne, Commodity of Care, 10. 
to pressure for expansion and rationalization in the early 1990s, the NDP government adopted some incremental reforms aimed at integration and consolidation of home care service delivery. Legislation adopted in 1994 called for the implementation of multiservice agencies under a system of quasi-public delivery to address the issue of fragmentation. However, this model was never implemented, leaving the door all the more open for the new Progressive Conservative (PC) government to reverse direction in 1996 toward implementing a system of "managed competition."

The new managed competition system involved the statutory creation of 43 regionally defined organizations called Community Care Access Centres (CCACs).$^{19}$ CCACs were charged with allocating entitlement to governmentfunded home care within their jurisdictions and were directed to purchase 100 per cent of these services from private-sector spos, selected under a mandatory competitive request-for-proposals (RFP) procurement process that awarded relatively short-term contracts (three to five years) subject to retendering. Both for-profit and non-profit SPOs were allowed to bid to obtain work, with no explicit preference for incumbent non-profit organizations. SPOs were considered the ostensible employers of record for front line care workers, and the CCACs did not directly employ their own care providers. ${ }^{20}$ Within the RFP process, bids were evaluated on a mix of quality and price indicators. Care services were generally priced under a piecemeal fee-per-visit model, at CCACdetermined hourly billing rates and fixed units of time for various tasks.

In part because sPOs themselves faced significant uncertainty under short-term contracts with CCACS, their relations with PSws were in turn often short-term in nature. Where SPOS lost CCAC contracts, workers would be terminated en masse, with many seeking re-employment at the new firm displacing the incumbent. Within similar occupations, significant wage gaps persisted between home care and other healthcare settings. ${ }^{21}$ Spos relied heavily on an insecure, casual employment model, although they referred to it more commonly, if somewhat inaccurately, as an elect-to-work model. While the elect-to-work label more accurately denotes a model in which workers have true freedom to choose whether/when to work, without penalty when not "electing" to work, the label seems historically to have been used as shorthand

\section{The 43 CCACs were consolidated into 14 in 2007.}

20. The employer status of the Spo for the purposes of Ontario's Labour Relations Act, 1995 (OLRA) (so 1995, c 1, Sch A) was to some extent challenged, unsuccessfully, within certain proceedings before the OLRB, discussed earlier. This challenge was based primarily on the degree of control that the CCAC exerted over the work performed by home care workers in the system and the allegation that the CCAC constituted a "related employer" along with the SPO, under s. 1(4) of the OLRA.

21. K. Parent \& M. Anderson, Homecare by Default, not by Design (Toronto: Canada's Association for the Fifty-Plus, 2001); Meredith B. Lilly, "Medical versus Social Work-Places: Constructing and Compensating the Personal Support Worker across Health Care Settings in Ontario, Canada," Gender, Place and Culture 15, 3 (June 2008): 285-299. 
for the overall model of piecework compensation and working-hours insecurity. Promoting use of this label historically also advanced spos' earlier strategy of claiming entitlement to related exemptions under the Employment Standards Act (2000) (ESA) previously available to employers in elect-to-work contexts, particularly exemptions from termination and severance pay obligations. ${ }^{22}$ Not surprisingly, by 2005 a survey commissioned by the Ontario government found that 40 per cent of home care workers surveyed felt either "not too secure" or "not at all secure" in their jobs. ${ }^{23}$

\section{Responses to Employment Conditions under Managed Competition}

VARIOUS POLICY RESPONSES have addressed the imposition of managed competition in the late 1990s and its effects on work and employment conditions. Arguably, the first major response came in 2004 in light of mounting concerns about quality of care under the new model and in response to lobbying and mass protests by unions and healthcare advocates. In response, the Liberal provincial government announced a moratorium on competitive bidding in the CCAC subsector and appointed Elinor Caplan to chair an independent review of the CCAC competitive bidding process. While some called for elimination of the system altogether, it was soon clarified that the Caplan review would focus more narrowly on CCAC procurement practices, taking the continuation of competitive bidding as a given.

The 2005 Caplan Report provided extensive criticism of CCAC procurement practices and recommended a large number of reforms. ${ }^{24}$ Increasing quality of patient care and home care worker employment conditions were identified as key objectives and the report linked deterioration in both of these to procurement practices. Caplan also drew causal connections between declining quality of care and worsening employment conditions. One of the report's key recommendations was a shift to longer-term contracts with SPOS in order to reduce disruption caused by regular contract switching. Other recommendations were aimed at incorporating so-called good employment practices into CCAC procurement criteria, along with other indicators of "quality" that the report suggested had been suppressed in favour of cost factors. Aside from lengthier contracts, the recommendations aimed at improving employment conditions included the following:

- a "preferred provider" designation based in part on good HR/employment practices;

22. See also Termination and Severance of Employment, O Reg 288/01, ss. 2(1) (10) and 9(1)(9).

23. Pollara Strategic Public Opinion and Market Research, CCAC Procurement Review Quantitative Survey Results (March 2005), 33, 35.

24. Ontario, монцтс, Realizing the Potential of Home Care: Competing for Excellence by Rewarding Results (Toronto: CCAC Procurement Review, 2005) (hereafter Caplan Report). 
- a points system for good HR/employment practices;

- cross-system standardization of certain employment conditions (dental, drug plans, pension, mileage) to be set by the Ontario Association of Community Care Access Corporations (OACCAC) and service provider associations;

- elimination of the "elect-to-work" model as described in the ESA regulations on home care so that all workers receive full coverage under the ESA related to paid statutory holidays, notice of termination, and severance pay;

- establishment by the OACCAC of a steering committee with provider associations and the Ontario Hospital Association to begin necessary planning for the elimination of elect-to-work;

- removal of barriers to entry into the home care workforce (including that CCACs not require 100 per cent PSW status and that employers commit to training and supervision of workers up to PSW status for two years); and

- evaluation of PSW training by the MOHLTC and Ministry of Colleges and Universities.

The procurement review found that the "vast majority of PSws work under the elect-to-work model." ${ }^{25}$ Importantly, the review problematized the distinction between the structure of the so-called elect-to-work employment relationship and the legal consequences of using this structure under existing law at that time. In a bona fide elect-to-work relationship, the worker has the right to elect whether to work, without threat of repercussion when he or she elects not to work. Where this was the true relationship, regulations under the $E S A$ at the time exempted employers from certain obligations. ${ }^{26}$ As the Caplan Report noted, employers broadly took advantage of these exemptions, especially in relation to PSws, such that PSws had the least access to any termination pay, severance pay, or statutory-holiday pay protections. ${ }^{27}$ Evidence provided to the review process also confirmed that the majority of PSws working under this model actually wanted either full-time or part-time employment, and thus the key characteristic of the so-called elect-to-work model highlighted in the report was the insecurity in working hours that it embodied; as such, it would be more accurately referred to as a casual model. In any event, the Caplan Report ultimately recommended both the elimination of reliance on this model of work allocation and the elimination of firms' access to the statutory exemptions provided in elect-to-work contexts. ${ }^{28}$

25. Caplan Report, 28.

26. Parent \& Anderson, Homecare by Default; Lilly, "Medical versus Social Work-Places."

27. Caplan Report, 28.

28. Caplan Report, 25-29. 
In 2006, the government announced its official response to the Caplan Report. ${ }^{29}$ Most directly relevant to Psw employment conditions were the adoption of the shift to longer-term contracts of up to nine years with increased dependence on quality criteria in awarding and renewing contracts; a promise to compensate PSWs for mileage and travel time; a promise to direct the OACCAC to "take steps to improve job stability and compensation"; a promise to "develop targets for full-time and regular part-time Psws"; a promise to work with CCACs to offer SPOs incentives to pay statutory-holiday pay and severance and termination pay; and, finally, a PSW hourly minimum wage of $\$ 12.50$ imposed under CCAC contracts. While these were improvements, the government refused to implement the central recommendation, to eliminate sector-wide reliance on casual employment. Instead, widespread casual employment continued but with a minimum-wage increase, some improved access to legislated minimum employment standards, and some targets in forthcoming procurement rules aimed at increasing the number of full-time and part-time positions.

\section{The New 2007 CCAC Procurement Rules}

The MOHLTC Adopted A NEW SET of CCAC procurement rules in 2007. ${ }^{30}$ Under the new rules, CCACS were supposed to require spos to reimburse their PSW employees at a minimum hourly rate of $\$ 12.50$, but the new rules also specified that this minimum wage would be narrowly restricted to graduates of recognized PSW training programs. CCACs were also directed to ensure that spos reimbursed PSWs for travel time, as required by existing law. This was a very limited improvement insofar as it did not impose any specific requirements or provide any specific direction to employers, who were already covered by existing law (requiring payment of travel time). As well, the new rules did not provide for any standardized employment conditions in the sector (e.g. dental, drug plans, pension), leaving these matters to continue to be determined strictly at the level of employment bargaining, contrary to both the Caplan Report's recommendation and the government's promise that these standardized conditions would be developed. Finally, the new rules contained only minimal targets for the creation of full-time and part-time jobs. The new rules required that under each contract, 20 per cent of personal support service volumes be delivered by PSws in part-time jobs and 10 per cent be delivered by PSws in full-time jobs. These jobs were defined as positions with regular workweeks of at least 30 hours and 15 hours, respectively, which in both cases employers could average over two-week periods. These

29. Ontario, монцтc, Choosing Quality, Rewarding Excellence: Ontario's Response to the Caplan Report on Home Care (Toronto: Queen's Printer for Ontario, 2006).

30. Ontario, монцtc, Client Services Procurement Policy for Community Care Access Centres (Toronto: Queen's Printer for Ontario, 2007). 
changes left substantial uncertainty over working hours intact, even where these targets were met. spos were also allowed a four-year phase-in period to achieve these targets, following which a full 70 per cent of all PSW service volumes could still legally be delivered by casual employees. ${ }^{31}$

Although no data on the enforcement of these procurement standards is publicly available, certain evidence suggests a bias toward neglecting their enforcement. The government, the CCACS, and the OACCAC each took the position historically that the CCACS and the OACCAC were not government bodies and thus not bound by freedom of information disclosure obligations. In any event, each group took the position that such disclosure would risk violation of the protection of the SPOS' proprietary information. Neither the OACCAC nor the MOHLTC ever published any report outlining SPO compliance with these procurement standards. Further, enforcement was almost entirely based on SPO self-reporting. SPOS were expected to voluntarily disclose their progress in meeting targets, and where they disclosed difficulty, the CCACs and/or the OACCAC would try to help the SPO move toward compliance. ${ }^{32}$ The standardized CCAC contract also provided for the CCAC's right to conduct an SPO audit, but this instrument was not used. By 2011, although the employment targets had been in effect for four years, based on an unpublished internal report, only 71.5 per cent of spos had met the targets..$^{33}$

Separate legislative enactments also served as a pretense for laggard job target achievement in the CCAC subsector. In 2009, in the middle of the four-year phase-in period of the job targets, Ontario's Bill 139 made certain amendments to the ESA. ${ }^{34}$ These included the removal of exemptions in electto-work contexts for public-holiday pay and termination and severance pay, giving elect-to-work employees the same rights as other employees with respect to these rules. These amendments were of general application and not targeted at the home care sector and were related to issues (termination, severance, and public-holiday pay) separate from the job targets in the procurement rules. Despite this, the OACCAC subsequently interpreted Bill 139 as sufficiently improving elect-to-work jobs in the CCAC subsector, making enforcement of the procurement employment standards less of a concern.

\section{Ontario, MонLtc, Client Services Procurement Policy, 8.}

32. From 2008 to 2011, CCACs transferred $\$ 27$ million to spos "to assist their efforts to increase the number of hours allocated to full-time staff." This is stated in an unpublished internal report undertaken by the CCACs, cited in Health System Labour Relations and Regulatory Policy Branch, Health Workforce Planning and Regulatory Affairs Division, "Findings and Proposed Next Steps: Enhancing Full-Time and Permanent Employment for Personal Support Workers in the Home and Community Care Sector" (confidential discussion notes), March 2016. These notes were produced under Freedom of Information request \# A-2016-00230/KD.

33. Health System Labour Relations and Regulatory Policy Branch, Health Workforce Planning and Regulatory Affairs Division, "Findings and Proposed Next Steps."

34. Employment Standards Amendment Act (Temporary Help Agencies), 2009, so 2009, c 9. 
Consistent with this, once the four-year phase-in of the job targets expired in 2011, the OACCAC stopped collecting records relating to compliance with these rules and stopped performing further analysis on these issues. To date, casual employment remains widespread. Indeed, in its 2015 submission to the $\mathrm{CWR}$, the association representing home care SPOS confirmed that approximately 80 per cent of home care workers remained employed under the casual model. ${ }^{35}$

Overall, in the half decade following 2006, various factors constrained the initial response to PSW employment precarity that the Caplan Report had promised. The Caplan Report's initial recommendation to eliminate casual employment was softened in the government's official response to the establishment of mere targets for non-casual jobs, which then became subsequently rather small targets in the procurement rules. Eventually, enforcement of even these minimal targets became a non-priority, largely hidden from public view, under the opacity of the ostensibly non-governmental competitive bidding governance structure.

\section{The Collective Bargaining Realm}

IT IS WELL KNOWN THAT SIGNIFICANT effects of privatization relate to labour cost differences, further driven by differences in union coverage and employer strategies between the public and private sectors. ${ }^{36}$ Building upon prior literature on the misfit between the North American Wagner model of labour law and modern organizational contexts, Tom Archibald traced the ways in which the Wagnerist regime suppressed worker organizing and the bargaining power of care workers under the managed competition regime, insofar as organizational structure and work relations in the sector did not align with classic assumptions embedded in labour law. ${ }^{37}$

\section{Home Care Ontario, "Re: Submission to the Ministry of Labour Consultations: Changing Workplaces Review, Supplementary Information," 2 November 2015, https://cirhr.library. utoronto.ca/sites/cirhr.library.utoronto.ca/files/ontario_workplace_review/Home $\% 20 \mathrm{Care} \% 20$ Ontario\%20Supplementary-Nov\%202015.pdf.}

36. Mark Thompson, "The Industrial Relations Effects of Privatization: Evidence from Canada," in Gene Swimmer \& Mark Thompson, eds., Public Sector Collective Bargaining in Canada: Beginning of the End or End of the Beginning? (Kingston: IRC Press, 1995), 164-179.

37. For prior literature, see, for example, Katherine V. W. Stone, "The New Psychological Contract: Implications of the Changing Workplace for Labor and Employment Law," UCLA Law Review 48 (2001): 519. Tom Archibald, "Collective Bargaining under Managed Competition in Health Care: The Ontario Home Care Experience," Queen's Law Journal 28 (2003): 581-636. Archibald describes the assumptions embedded in Wagnerist labour law as being (a) "classic employer" assumptions (that firms are presumed to be large, stable, vertically integrated entities); (b) "classic job" assumptions (that work is organized in full-time, stable, long-tenure employment relations); and (c) "subordination" assumptions (in particular, that workers are not professionals and thus strike action is not particularly constrained by ethical or moral concerns about work interruption). 
Canada's Wagner model is primarily suited to enhancing employee bargaining power in single, large, vertically integrated organizations, as opposed to modern disaggregated, fissured, interfirm organizational structures. ${ }^{38}$ Under the managed competition home care regime, fragmented allocation of classic employer functions/powers across both SPOs and the CCACs was acknowledged as a reality by the Ontario Labour Relations Board. Yet, this recognition did little to alter the balance of power in the workplace. In the 2000 OLRB case Durham Access to Care, the applicant unions sought to have the local CCAC and its SPO subcontractors declared as a "related employer." ${ }^{39}$ Were this to be recognized, it would have created a common bargaining structure binding both organizations exercising employer functions to the same collective bargaining process and outcomes. It would have also increased workers' ability to bring collective bargaining power to bear more directly upon the government as funder and simultaneously reduce wage-based competition within each region.

The OLRB ultimately dismissed the unions' request. Notably, however, it made this decision after first finding that the relationship between the CCACS and SPOs actually satisfied the legal test for a "related employer." ${ }^{\text {"40 }}$ Despite this, the OLRB relied on its discretionary power in dismissing the application, invoking a more general concern with limiting unions' use of the related employer mechanism to expand bargaining rights upstream and avoid the certification process. ${ }^{41}$ In bald policy terms, the OLRB's move can be interpreted here as erring toward protecting government capacity not only to contract out as it wishes but also to achieve a desired lowering of the level of collective bargaining, post-contracting out.

Other limitations of the labour law regime identified by Archibald relate to its implicit assumptions of standard employment relationships, particularly those involving lengthy, full-time jobs, with resulting workplace attachment increasing workers' attraction to collective bargaining. ${ }^{42}$ Rather, under managed competition, casual and short-term employment is widespread, reducing workers' attachment and willingness to absorb the costs/risks of union organizing. Further, the model provides the strike as the primary dispute resolution mechanism, as opposed to interest arbitration, which is

38. Weil, Fissured Workplace.

39. Durham Access to Care [2000] olr B Rep. September/October 855. See s. 1(4) of the OLRA.

40. Durham Access to Care, September/October 855.

41. Durham Access to Care, [2000] O.L.R.B. Rep. November/December 1108. The OLRB was influenced by the observation that unions in this sector initially tried to organize and bargain in the normal fashion, acquiescing to the notion of the subcontractor as the sole employer. Unions have regularly criticized this reasoning, pointing out that they lack information about the nature of employer-side organizational relations.

42. Archibald, "Collective Bargaining." 
provided to many other healthcare workers. ${ }^{43}$ This bargaining dispute resolution mechanism is somewhat contradictory to the professional dimension of the PSW occupation, insofar as many PSWs, like other health system professionals, have significant ethical restrictions on withdrawing their labour based on concerns for the health and welfare of their clients.

While Archibald's early analysis of legal structure paints a rather bleak picture of the potential efficacy of unionization in this sector, worker and union agency obviously still exist and thus actors' strategic choices within the regime may matter. Further, slight policy changes to this structure occurred beginning with the 2004 moratorium and the related responses discussed above. Further, after a protest in 2008 during the Hamilton CCAC's bidding competition that threatened to eliminate two long-standing providers, including the von, the government declared another moratorium on new rounds of competitive bidding. Then in 2012, shortly after the election, the Liberal government announced a further continuation of the moratorium, which remains in place. Effectively, a slightly modified model of the original managed competition system has been in place since the middle of the 2000s. This modified system is based on longer service contracts with greater likelihood of being renewed under negotiation with government instead of being put out to competitive tendering. Moreover, in considering contract renewal, comparably more weight is officially placed on quality factors in procurement. This modified regime theoretically makes it somewhat more possible for unionization to gain a foothold, since the lengthier service relationships between CCACs and SPOs that it fostered potentially increased employment tenure, worker attachment, and potential gains from unionization. As well, the increased likelihood of renewal and further emphasis placed on quality may have also reduced labour-cost-based competition.

\section{The Collective Bargaining Realm: Union Organizing}

FOLLOWING THE EARLY IMPOSITION of managed competition, the main union representing PSWs in the subsector was the Service Employees International Union (SEIU), which from its very early years had formed a single large composite local union representing all of its healthcare worker members in the province. On the employer side, the Red Cross was from the outset the largest employer of PSWs, employing more than 3,500 PSWs in the CCAC subsector. In the mid-1990s, the Red Cross and the SEIU came to an agreement that newly organized groups of Red Cross workers - which, in formal legal terms, were separate bargaining units defined by municipal boundaries - would be covered under the existing collective agreement. This arrangement created, at

43. In Ontario, employees of hospitals and certain other institutional facilities are provided access to interest arbitration under the Hospital Labour Disputes Arbitration Act (HLDAA) (Rso 1990, c H.14). 
least in a de facto sense, a province-wide collective agreement. The first agreement for what the parties labelled the "Ontario Zone" took effect in 1999. For the union, this arrangement enabled efficiency in organizing and representing Red Cross PSWs on a broader basis. After the 1996 imposition of managed competition, the province-wide bargaining arrangement with the Red Cross became all the more significant. In the mid to late 1990s, the SEIU was able to expand its membership foothold in the subsector primarily through a strategic focus on adding remaining groups of Red Cross Psws and eventually held bargaining rights at virtually all Red Cross locations in the province. However, apart from this, informants report that organizing in the subsector suffered under the constraints imposed by managed competition, such that by the early 2000 s, the SEIU had significantly withdrawn from organizing activities.

However, around the time of the 2004 moratorium, the SEIU increased its prioritization of home care organizing. This strategic initiative was furthered by support from the SEIU International parent union, based in the United States under the leadership of Andy Stern. Under Stern's organizing model, the SEIU had been experiencing some success in home care organizing in the United States and subsequently turned its attention toward supporting home care organizing in Ontario. For a few years after 2004, the SEIU International provided SEIU Healthcare Ontario with what a union staff member informant described as a "huge investment" of resources aimed at home care sector organizing. Although there are important institutional differences, such as the lack of employee status and the need to confront the exclusion of workers under the Fair Labor Standards Act in the United States, there also existed certain parallels, including the importance of bargaining structure. A significant determinant of the SEIU's organizing success in the United States was the union's ability to construct some political mechanism enabling bargaining with government directly. ${ }^{44}$ This political relationship was lacking from the outset in the Ontario context. The union nevertheless felt, at least for some time, that other contextual conditions made the chances of successful organizing of PSWs in Ontario sufficiently high to justify a relatively large campaign and resource allocation. SEIU home care organizing thus expanded significantly beyond the Red Cross base toward other spos.

While some membership growth occurred as a result of this organizing push, by 2007 support from the international parent union had shifted toward organizing in long-term care facilities, considered more amenable terrain than the CCAC subsector. Organizing in the CCAC subsector continued, but without the initial extraordinary support from the United States, and thus on a comparably smaller scale. By 2017, the SEIU represented approximately 8,000 PSws, with the Canadian Union of Public Employees (CUPE) and Ontario Public Service Employees Union (OPSEu) also emerging in the 
sector to represent approximately 1,000 PSWs each. While official statistics are not available, various informants felt that union density in the subsector has hovered around 30 per cent over the past decade. Informants also reported that although organizing remains very difficult for many reasons, the postCaplan Report developments in the mid-2000s somewhat improved viability.

\section{The Collective Bargaining Realm: Bargaining Outcomes}

GAINS FROM COLLECTIVE BARGAINING for PSWS have been fairly modest under managed competition. As noted above, a database containing a sample of 81 collective agreements from 1999 to 2015 has been created to track worker gains in the sector. Different categories of collective agreement terms were clustered and reviewed in order to try to identify trends in bargained outcomes over time within different categories, including seniority, hours of work, scheduling, travel pay, extended health benefits, overtime/shift premia, and retirement benefits. As well, informants provided further helpful explanations of bargaining outcomes and trends over time.

Certain key observations can be made about patterns in bargained outcomes for PSWs under managed competition. First, despite the Caplan Report having identified it as highly problematic, subsequent collective bargaining has not produced a significant departure from the norm of widespread use of the casual, insecure-hours employment model. Very few collective agreements require employers to provide any form of working-hours guarantee. Several collective agreements contain provisions that attempt to define a full-time or part-time position, or, less commonly, refer to a subcategory of employees as "shift employees," suggesting that the employer will in practice offer some subset of employees some fixed hours of work. In these contexts, some of these collective agreements also specify other rights attaching to full-time or part-time positions, such as limitations on how often these employees will be required to work weekends. Importantly, however, PSW employers appear to have extremely few obligations to create full-time or part-time positions, and the piecemeal work assignment and payment practices imposed unilaterally by the CCACs constrains the creation of those positions. A few collective agreements contain language addressing the rights of fixed-hours employees in the event that fixed-hours positions are mandated by government.

One collective agreement contains a requirement that 5 per cent of total service volumes assigned to workers by the spo be assigned to full-time and 10 per cent to part-time workers, which is oddly a standard below that imposed by the 2007 procurement guidelines. ${ }^{45}$ One Toronto-area collective agreement for 2003-05 contained language requiring the employer to "endeavour" to establish full-time and part-time-hours positions for 30 per cent of its CCAC 
service volume, yet this provision was removed in the subsequent agreement. Overall, the collective bargaining pattern is clear. The casual, insecure-hours model has remained the widespread norm throughout the sector, with only small portions of the PSW workforce provided with some measure of certainty in hours of work.

Within the confines of the paradigmatic casual model, unions seem to have made some minor gains over time relating to non-wage items, including some control over working hours. Some collective agreements require advance notice of schedules. Some specify that for full-time or part-time workers, notice will be longer - up to four weeks ${ }^{46}$ - but for most other employees, around one week's notice seems to be typical. Many collective agreements specify various factors for the employer to consider in work allocation, and seniority is commonly cited among other factors. In only a few select cases, the collective agreement specifies that where certain other factors are "relatively equal" seniority prevails, which is a somewhat stronger seniority arrangement, albeit one that still leaves much discretion in the hands of the employer.

Also relevant to scheduling are rules about when and how workers are supposed to submit their "availability" to employers. Minor variations to these rules have seemingly occurred over time in many organizations, as unions have sought to place limits on required availability in terms of total hours and during certain time periods. Yet, when viewing the sector as a whole, no clear positive trend is apparent. Also, relevant to working hours and scheduling are terms relating to overtime and other shift premia. While a few collective agreements specify overtime thresholds that are below (i.e. better than) the 44 hours per week specified in the ESA, most seem to allow employers to take advantage of the opportunity to "average" hours over a two-week period, where specified in an agreement, reducing worker entitlement to overtime pay. ${ }^{47}$ There appeared to be some pattern of improvement in terms of shift premia, with many of the more recent collective agreements containing shift premia for evening and/or weekend work, ranging in amount from an additional fifteen cents to one dollar per hour. ${ }^{48}$

A problematic pattern that the Caplan Report identified in the mid-2000s was the nonpayment of travel pay to many home care workers. Since then, a positive trend is apparent: most collective agreements now formally provide PSWs with some sort of compensation for travel, through a variety of different kinds of formulae across collective agreements. ${ }^{49}$ However, the adequacy of

46. See, for example, the collective agreement between the Ontario Public Service Employees Union and the von for the Hamilton region, 2008-10.

47. See s. 22(2) of the Employment Standards Act, 2000 (so 2000, c 41).

48. See, for example, the collective agreement between the Ontario Public Services Employees Union and the von in the North Bay/Parry Sound region, 2008-12.

49. Some are based on actual time spent travelling, and others use distance as the only variable, while yet others use measures of both time and distance. Some of these agreements 
existing compensation arrangements for travel time has remained a significant source of dispute. ${ }^{50}$

About 60 per cent of all collective agreements seem to refer to the existence of some sort of retirement savings plan (RSP) or pension plan, while the rest do not. However, in these collective agreements in which a plan is referenced, the majority make this benefit available only to full-time and part-time employees, which typically comprise only a small subset of employees. In a few other collective agreements, workers are provided with some additional pay "in lieu" of any retirement or pension benefit. As a very recent positive trend, the 2016-19 collective agreement between the SEIU and Care Partners (the successor to the Red Cross in its CCAC-based home care operations), contains a new requirement that the employer contribute 2 per cent of gross earnings, up to a maximum of $\$ 1,000$ per year, to an RSP.

As for extended health benefits, the clear pattern appears to be that workers not designated as full-time or part-time employees continue to have no employer-provided benefits, despite the Caplan Report's call for benefit provision to become standardized across the subsector. Where collective agreements require employer-paid benefits, some provide them to both fulltime and part-time employees, while some limit them to full-time employees. Agreements might also provide for some sort of payment in lieu of benefits to full-time and/or part-time employees. There appears to be no clear pattern of improvement in this area.

As with other terms, wages for Psws vary somewhat across SPOs, because of the decentralized bargaining structure and potentially also owing to historical grandfathering of some SPO-specific billing rates in certain cases. However, key informants suggested that outcomes in the large SEIU/Red Cross province-wide bargaining unit have historically served as key baseline standards influencing negotiated outcomes with other SPOS across the sector, and particularly the unionized portion of the sector. ${ }^{51}$ The SEIU/Red Cross wage grid differentiates between various categories and levels of training for homeworkers/PSWs, so measures of wage growth need to be based on these differentiated categories. Using wage rates for "level 1" and for "level 6" (the lowest and highest rates available for what are now referred to as PSws,

have time caps while others convert distance into time worked based on assumptions of average speed. Others provide for variations based on longer travel in rural areas, while another simply provides a 15 per cent top-up of all hours worked as a fixed travel allowance.

50. Strengthening worker protection for travel time compensation was one of the four recommendations made in the initial submission of the SEIU, Local 1, Canada (the largest union in home care) to the Changing Workplaces Review consultation process. See SEIU Local 1 Canada, "RE: Submission to the Changing Workplaces Review," n.d. [2015], https://cirhr. library.utoronto.ca/sites/cirhr.library.utoronto.ca/files/ontario_workplace_review/sEIU.pdf.

51. This is not to suggest that the Red Cross has paid the highest rates. It seems that the von, a non-profit provider of PSW services, has tended to pay the highest PSW wages in the sector over time. 
previously homemakers), Table 1 provides collectively bargained wage rates from 1999 to 2016.

The data in Table 1 show that from the years 1999 to 2015, Psw wages grew approximately 38 or 39 per cent, depending on which level is used as measurement. During this same period, the average hourly wage rate in Ontario grew 55.8 per cent across all industries and 55.3 per cent in the NAICS category of "healthcare and social assistance." 52 Occupation-based data shows that average hourly wages in Ontario during the same period grew 50.5 per cent across all occupations, 49.7 per cent in the category of "health occupations," and 52.7 per cent in the aggregate category called "care providers and educational, legal and public protection support occupations." 53 By various comparisons, PSW wage growth in this unionized subsector was substandard for over a decade and a half.

Interestingly, the data in Table 1 also show that wage growth was larger, in percentage terms, in the earlier years of managed competition than in the later post-Caplan Report period. The lack of wage growth is surprising given that reforms marginally improved the efficacy of Wagnerist collective bargaining within the managed competition regime. Informants explained that the more recent wage trend was largely the result of more severe austerity measures in the second half of the first decade of the 2000s, including, particularly, a freeze on CCAC billing rates. A 2013 research report initiated at the request of the CCACS and SPOs noted that SPOs experienced rate freezes in two to four of the prior six years. ${ }^{54}$ Because unions were unable under the bargaining structure imposed by labour law to bargain directly with government over PSW wages, collective bargaining produced minimal wage growth in the post-Caplan Report period. ${ }^{55}$ These low wage-growth patterns set the context for ongoing lobbying, public relations campaigns, and coalition building that would culminate in a significant ad hoc ministry intervention into home care labour relations in the form of the 2014 PSW Wage Enhancement Initiative.

\section{The 2014 PSW Wage Enhancement Initiative}

THE HR ISSUES OF RECRUITMENT and retention of PSWS remained ongoing and salient concerns in the years leading up to the 2014 election. At the same time, healthcare restructuring continued to move toward increased reliance on PSWs, a recommendation by the influential Drummond Report on

52. Statistics Canada, "Employee Wages by Industry, Annual," Table 14-10-0064-01, accessed 7 July 2020, https://doi.org/10.25318/1410006401-eng.

53. Statistics Canada, “Employee Wages by Occupation, Annual," Table 14-10-0307-01, accessed 7 July 2020, https://www150.statcan.gc.ca/t1/tbl1/en/tv.action?pid=1410030701.

54. Accenture, Fee-for-Service, 19-40.

55. Accenture, Fee-for-Service, 40-41. 
Table 1. Selected PSW/Homemaker Wage Rates, SEIU/Red Cross Ontario Zone Collective Agreements, 1999-2016

\begin{tabular}{|c|c|c|c|c|}
\hline Date & Level 1 wage & Lump sum & Level 6 wage & Lump sum \\
\hline 1 April 1999 & $\$ 10.06$ & & $\$ 11.16$ & \\
\hline 1 August 2008 & $\$ 12.91$ & & $\$ 14.29$ & \\
\hline 1 February 2011 & $\$ 13.64$ & & $\$ 15.02$ & \\
\hline September $2011 \& 2012^{a}$ & $\$ 13.64$ & $\$ .15 / \mathrm{hr}$ & $\$ 15.02$ & $\$ .15 / \mathrm{hr}$ \\
\hline 1 April $2013^{b}$ & $\$ 13.64$ & $\$ .19 / \mathrm{hr}$ & $\$ 15.02$ & $\$ .21 / \mathrm{hr}$ \\
\hline 1 April 2014 & $\$ 13.83$ & & $\$ 15.23$ & \\
\hline 1 April 2015 & $\$ 14.02$ & & $\$ 15.44$ & \\
\hline \% increase 1999-2015 & $39.4 \%$ & & $38.4 \%$ & \\
\hline$\%$ increase $1999-2008$ & $28.3 \%$ & & $28.0 \%$ & \\
\hline$\%$ increase $2008-15$ & $8.6 \%$ & & $8.0 \%$ & \\
\hline
\end{tabular}

a In the 2011-13 agreement, wages are set as of 1 February 2011, but in September 2011 and September 2012 , employees are entitled to a retroactive lump-sum wage payment of $\$ 0.15$ per hour, in lieu of a compensation adjustment, for hours worked during the previous 26 pay periods.

${ }^{b}$ In the 2013-16 agreement, imposed by an interest arbitration award, a lump-sum payment of 1.4 per cent in lieu of compensation adjustment is payable for hours worked from April 2013 to March 2014. In subsequent years, wage rates increased by 1.4 per cent per year.

public-sector restructuring. ${ }^{56}$ Indeed, this process was already underway, given the task-shifting and downloading of a broader scope of health-related duties to the PSW position within home care, intensifying the need to address the underlying causes of the retention and recruitment problem. ${ }^{57}$ Acknowledging both the need for improved employment conditions and the lack of progress on this, a confidential 2012 report of the Health Human Resources Strategy Division of the MOHLTC, which summarized policy initiatives designed to address PSW retention and recruitment, admitted that "while these initiatives are important, it has been reported that they have had minimal impact with

56. Ontario, Commission on the Reform of Ontario's Public Services, Public Services for Ontarians: A Path to Sustainability and Excellence (Toronto: Queen's Printer for Ontario, 2012).

57. Margaret Denton, Catherine Brookman, Isik Zeytinoglu, Jennifer Plenderleith \& Rachel Barken, "Task Shifting in the Provision of Home and Social Care in Ontario, Canada: Implications for Quality of Care," Health E Social Care in the Community 23, 5 (September 2015): 485-492. 
regards to improving the working conditions for PSws or addressing major wage concerns." ${ }^{58}$ Given that low wages were a key concern identified by PSws themselves in recent surveys, the ministry chose the extraordinary measure of a wage enhancement instrument as its core intervention. ${ }^{59}$

The minority Liberal government outlined its PSw home care wage enhancement plan in its 2014 budget, promising PSWs a three-stage wage increase as follows: an additional \$1.50/hour effective on each of 1 April 2014 and 1 April 2015 , and a further $\$ 1.00$ /hour effective 1 April 2016. The government also set new minimum hourly base wages for personal support services in the home and community care sectors at $\$ 14.00, \$ 15.50$, and $\$ 16.50$ as of 1 April in 2014, 2015, and 2016, respectively. Despite pleas from the SEIU and some other unions, the NDP refused to support the government budget, forcing an election. ${ }^{60}$ Media reports highlighted the resulting schism between the New Democratic Party and various unions that favoured aspects of the 2014 budget, delivering substantial union support for the Liberals in the election, particularly from the aggrieved SEIU, whose extraordinary PSW wage breakthrough hung in the balance.$^{61}$ Following its victory, the majority Liberal government began implementing its promised PSW wage increase in the home care sector.

Implementation of the PSW wage increase was not a straightforward exercise. SPOs were required to file compliance with the new measures with the Local Health Integration Networks but raised various complaints about the initiative. These complaints ranged from confusion about worker eligibility and the precise scope of the initiative's application outside the CCAC subsector to the lack of extra funds provided for SPO administration in its implementation and the compression effect that it had on existing wage distributions between PSws and other job categories. This latter concern was particularly significant for the unions, who claimed that it raised issues of morale and related wage

58. See Ontario, монцтс, Ontario's Action Plan for Health Care: Opportunities for the Development of a Personal Support Worker Strategy, Health Sector Labour Market Policy Branch, Health Human Resources Strategy Division (Toronto 2012). The previous initiatives cited in the report included the establishment of the Psw Registry; the development of some common PSW educational standards; a survey of PSW work conditions; the enactment of a fund to support PSW training in the community sector; the 2006 PSW stabilization strategy to support PSW base wages and travel compensation (in implementing the government's response to the Caplan Report) and new positions in long-term care homes; and revisions to the Employment Standards Act that gave "elect-to-work" employees the same rights to public holiday pay and termination pay as other employees.

59. Janet Lum, Jennifer Sladek \& Alvin Ying, "Ontario Personal Support Workers in Home and Community Care: CRNCC/PSNO Survey Results," In Focus Backgrounder, Canadian Research Network for Care in the Community (CRNCC), Toronto, 2010; Janet Lum et al., Ontario Psw Registry Data Analysis Results (2013).

60. Martin Regg Cohn, "How Andrea Horwath Defied Homecare Plea from Union," Toronto Star, 21 May 2014.

61. Regg Cohn, "Andrea Horwath." 
pressure from workers in other job categories. The wage enhancement initiative also did not take into account gaps in PSW wages across different SPOS. Following ongoing stakeholder consultations during implementation, in April 2016 the government imposed a cap, such that the hourly increase of $\$ 1 /$ hour due on 1 April 2016 would only be required (and funded) up to a maximum wage of $\$ 19$ /hour with government estimates suggesting that approximately 86 per cent of PSWS would thereafter be earning a wage greater than $\$ 18 /$ hour. $^{62}$

\section{The PSW Registry and Other Reforms}

DURING AND AFTER THE implementation of the wage enhancement initiative, various other proposals relating to enhancing PSW employment conditions were floated for consideration. Many of these proposals included the development of a new scheduling model to increase stability in hours, improved PSW training measures, standardized CCAC billing rates, and professionalization of the PSW occupation. Regarding professionalization, the government initiated a process in the late 2000s toward the development of a new PSW registry, which was eventually launched in 2011 . While the registry would ostensibly serve as an additional step toward professionalization, it was also potentially helpful to union formation by providing unions with further information about and improved access to PSWs in the sector. Following public criticism of its eligibility criteria, accuracy, complaints process, and general lack of public oversight, the registry was cancelled in January $2016 .{ }^{63}$ Subsequently, in February 2018, the government launched a revised PSW registry that addressed some of the critiques of the previous model and provided for a minimal complaints process. ${ }^{64}$ To date, this registry remains in effect.

The Liberal government announced one other major reform measure in 2017: a new public agency, called Self-Directed Personal Support Services Ontario (SDPSSO), intended to serve as a model for direct government delivery of home care. ${ }^{65}$ This new agency would have implemented the principles of

62. See Ontario, монцтс, "2016 Addendum to the Directive to Local Health Integration Networks on Personal Support Services Wage Enhancement," Toronto, 2016. The government's estimate was contained in confidential notes of a Minister's Briefing on 20 February 2015, revised 3 March 3 2015, entitled "PSW Wage Enhancement Initiative Years 2 and 3 Implementation Options," LHIN Liaison Branch, Health System Performance and Accountability Division, MOHLTC, produced under Freedom of Information request \# A-2016-00231/KD.

63. Diana Zlomislic, "Ontario Closes Personal Support Worker Registry," Toronto Star, 27 January 2016, https://www.thestar.com/news/canada/2016/01/27/ontario-closes-personalsupport-worker-registry.html.

64. Vjosa Isai, "Province Launches New Personal Support Worker Registry," Toronto Star, 26 February 2018, https://www.thestar.com/news/gta/2018/02/26/province-launches-newpersonal-support-worker-registry.html.

65. Ontario, Modernizing the Home and Community Care Sector, n.d.; Bob Hepburn, "Ontario 
increased "self-directed care" for certain patients, but it would have done so under a model of public delivery. These care providers were meant to be officially recognized as employees of the public agency. If this model had taken hold and expanded over time, it would have represented a potentially significant displacement of the managed competition model and related employment precarity, since it would have allowed for a more centralized collective bargaining structure with the government as the direct employer. This reform would likely have generated a virtuous circle of expanded union organizing and collective bargaining power. Indeed, in policy dialogue, the model was criticized as being a "political gift" to SEIU Healthcare insofar as it bundled the issue of self-directed care with a reorganization that favoured public-sector employment and unionization. Again, following the 2018 election, the new PC government announced the winding down of the SDPSSO. ${ }^{66}$

More extensive analysis of the various other initiatives discussed in this section is beyond the scope of this article. However, one final key response to PSW employment conditions, the 2015-16 CWR labour law reform process, followed shortly thereafter by pendulum swings in labour law enactments, is discussed in the next section.

\section{The Changing Workplaces Review and Bill 148}

The Changing Workplaces Review was a broad-sweeping review of both labour and employment law in Ontario. The review - historically unprecedented in its scope of its terms and consultation - involved an extensive two-stage consultation process, beginning with an initial consultation stage, followed by an interim report that identified a vast set of potential reforms. The commission then followed up on its interim report with subsequent consultation about specific options identified in the first stage of the review. Various issues of particular relevance to home care were salient, and the key employer association and unions filed multiple submissions. Bill 148 was enacted within days of the May 2017 release of the CWR Final Report, which took effect in November 2017.67

Most new provisions in Bill 148 were of general application, although one was explicitly directed at the home care sector. Employment standards reforms of general application with particular relevance to home care included new employee rights to advance notice in scheduling, and minimum payment entitlements for being on call. On the labour relations front, the bill mainly provided reforms to the organizing process. Under Bill 148, unions were

Home-Care Plan a Bold Step," Toronto Star, 8 November 2017.

66. Ontario, монцтс, "Self-Directed Personal Support Services Ontario Update," Health Update, Toronto, 31 August 2018, http://www.health.gov.on.ca/en/news/update/hu_20183108. aspx.

67. Fair Workplaces, Better Jobs Act, 2017, so 2017, c 22. 
entitled to request an order directing that the employer disclose to the union a list of proposed bargaining unit employees' names and contact information, once the union demonstrated a 20 per cent threshold level of membership in the appropriate bargaining unit. This provision was one of the few reforms specifically requested by the SEIU as being helpful in assisting home care PSW organizing. ${ }^{68}$

Other provisions slightly strengthened access to first contract arbitration, allowed for more freedom to revise bargaining unit structures over time (although still only among workers of the same, single employer), and strengthened the remedial certification provision. There was also a new "just cause" protection for workers fired post-certification but prior to a first collective agreement being reached and for workers fired during a strike or lockout. The right to return to work after a lengthy strike was also clarified, removing the prior six-month limitation. In addition to these reforms of general application, another new provision targeted home care, identifying the sector as one of three specified "industries" in which unions would be allowed access to a card-based union certification procedure. Contrary to the recommendation in the CWR Final Report, Bill 148 did not include home care as one of the contexts in which new "successor rights" would apply in cases of reassignment of the contract/work of the employer, leaving home care unions and workers vulnerable to complete loss of bargaining rights in these situations. The bill did, however, include a provision authorizing the minister to enact regulation that would extend these provisions to other industries in the future. Finally, the government neglected to take up the CWR's crucial recommendation to move toward the development of a model of broader-based bargaining in government-funded home care. ${ }^{69}$

Overall, Bill 148 reforms stood to marginally improve union organizing capacity while doing little to affect the balance of bargaining power post-certification. Crucially, in the managed competition subsector, the bill left intact the fragmented bargaining structure that had thus far insulated governmentas-funder from an effective bargaining process, enabling cost saving via severe wage constraint for the prior decade and a half. Nevertheless, shortly after the June 2018 election the new PC government scrapped most of Bill 148's reforms.

The Progressive Conservatives' bluntly titled "Open for Business Act" (Bill 47) received royal assent on 21 November 2018, and many of its provisions took immediate effect. ${ }^{70}$ Most of the ESA reforms of general application were repealed, while a few were retained. The new rights with respect to scheduling and "on call" pay were revoked, other than the right to receive at least three hours' pay where a worker who normally works more than three hours

68. SEIU Local 1 Canada, "RE: Submission."

69. Ontario, The Changing Workplaces Review: An Agenda For Workplace Rights, Final Report (Toronto: Queens Printer for Ontario, 2017), 26.

70. Making Ontario Open for Business Act, 2018, so 2018, c 14. 
has their shift reduced to less than three hours of work during the course of the day. Most of the reforms relating to labour relations that were of general application were also repealed, including access to the employee list, access to card-based certification for "specified industries" (which included home care), improved access to remedial certification, improved access to first contract arbitration, and increased protection of the right to return to work following a lengthy strike. The rules concerning bargaining unit restructuring were largely removed, although a new substitute provision provides somewhat more freedom in this regard than pre-Bill 148 law. Bill 47 also revoked the minister's power, extended under Bill 148, to extend the new successor rights rules to other industries, including home care.

\section{Conclusion}

THE ORIGINAL IMPOSITION of managed competition in the home care sector not only caused a significant degree of precarity, as previous research has shown, but also stimulated the emergence of a range of policy responses to these conditions over time. These responses were prompted by a combination of the salience of the resulting precarious employment outcomes, corresponding worker and patient activism in the home care sector, and government concerns about healthcare human resources.

The overall pattern of policy responses to the precarity of home care employment may be understood as being significantly mediated by its pre-existing institutional context. This institutional context included the commitment, since 1996, to a fissured organizational structure in home care service delivery based entirely on outsourcing, with a corresponding hyperdecentralized, ineffectual bargaining structure assigned by default by outdated labour law (reinforced by the OLRB's refusal to use its available tools to remedy this). This unyielding structure served as a key mediating constraint on the subsequent agenda of reforms that were considered and mediated the effects of various reforms adopted. Despite post-2004 reforms, most of this structure remained largely intact and continued to enable government to act as a quasi-monopsonist in restraining labour costs. ${ }^{71}$ Despite some union growth, collective bargaining in the sector produced extremely low wage gains, even after Liberal-imposed austerity undermined post-Caplan Report reforms to the managed competition system. Some sporadic non-wage gains were made, yet PSW employment outcomes en masse remained based on a casual platform, and unions lacked the necessary capacity within the existing bargaining structure to obtain significant reform over this key characteristic or other compensatory factors.

The most dramatic policy measure, the PSW Wage Enhancement Initiative, constituted a major, ad hoc overriding of this structure that had until then

71. Charlesworth, "Decent Working Conditions." 
delivered wage-based restraint so successfully that it challenged the government's own health human resources objectives. This reliance on such an extraordinary ad hoc wage-control measure, without addressing the core institutional structure, severely restricts the degree of progress in PSW employment outcomes capable of being produced by collective bargaining in Ontario home care. In the longer run, we will see if the development of the new model of direct government delivery of home care will once again proceed - a model that may have potentially displaced the managed competition regime to some degree and enabled more direct bargaining with government. Similarly, only time will tell if a future government is willing to develop a revised bargaining structure for government-funded home care, as suggested in the final report of the CWR labour law review process. These or other sorts of reforms that address this deeper institutional structure seem necessary in order to make more significant and politically sustainable improvements to home care PSW employment conditions.

The author wishes to gratefully acknowledge seed funding for this research provided by the SSHRC-funded project Poverty and Employment Precarity in Southern Ontario. The author also benefited from comments on previous drafts of this article by Andrea Noack, Ian Sakinofsky, and three anonymous reviewers. 